\title{
Asphaltene as Light Harvesting Material in Dye-Sensitized Solar Cell: Resurrection of Ancient Leaves
}

\author{
Abujnah RE ${ }^{1}$, Sharif $\mathrm{H}^{2}$, Torres $\mathrm{B}^{3}$, Castillo $\mathrm{K}^{4}$, Gupta $\mathrm{V}^{5}$ and Chianelli $\mathbf{R R}^{6^{*}}$ \\ ${ }^{1}$ Earth and Environmental Science Department, College of Science, Al-Mergeb University, Al Khums, Libya \\ ${ }^{2}$ College of Science, Al-Mergeb University, Al Khums, Libya \\ ${ }^{3}$ Materials Research and Technology Institute, University of Texas at El Paso, Texas, United Stated of America \\ ${ }^{4}$ El Paso Community College, El Paso, Texas, United States of America \\ ${ }^{5}$ Sandia National Laboratory, Albuquerque, New Mexico, United States of America \\ ${ }^{6}$ Materials Research and Technology Institute, University of Texas at El Paso, Texas, United States of America
}

\begin{abstract}
Asphaltenes are remnants of ancient photosynthetic plants and are today considered waste hydrocarbons that must be removed from petroleum for use as fuel and often find their use as road tar. This study reports the first time their use in Dye-Sensitized Solar Cells (DSSCs) in which light is converted to electricity with conversion efficiencies approaching $1.8 \%$. Extracted fractions of asphaltenes from Mexican Altamira crude oil were used as light absorbers in $\mathrm{TiO}_{2}$ based DSSCs. The photovoltaic performances of the cells were analyzed by determining the I-V cell parameters such as OCV (open-circuit voltage), SCC (short-circuit current), FF (fill factor), and SR (series resistance). The overall energy conversion efficiency was also measured to correlate the effect of the different asphaltene portions that created significant improvement of the solar cell parameters. The sensitization of $\mathrm{TiO}_{2}$ electrode with the best asphaltene fraction resulted in a maximum energy conversion efficiency of $1.8 \%$ for the solar cell with a maximum photocurrent density of $16.9 \mathrm{~mA} / \mathrm{cm}^{2}$. At this level the solar cell created has strong economic potential. A future strategy to further improve performance by minimizing series resistance and improving the photo current and open circuit voltage is also reported. The cells have shown excellent life as suggested by photo-catalytic polymerization of asphaltene materials when exposed to sunlight and air as stated in patent number 8,389,853.
\end{abstract}

Keywords: Asphaltene; Polymerization; Photovoltaic technology; Dye sensitized solar cells (DSSC)

\section{Introduction}

Photovoltaic solar cells have shown great promise in capturing solar energy and providing clean and renewable electrical energy that can reduce the world's dependency on fossil fuels, and reduce emission of $\mathrm{CO}_{2}$. However, in spite of the recent rapid growth of the solar industry, the high cost of photovoltaic solar cells has remained a limiting factor for the implementation of the solar electricity in a large scale. Currently, the dominant photovoltaic technology is based on solid-state $\mathrm{p} / \mathrm{n}$ junction devices, in which semiconductor absorbers produce a build-in electrical field separating electron-hole pairs and the electron-hole pairs, thus generating electricity when illuminated. These types of solar cells have high power conversion efficiency, but suffer from high manufacturing and material cost.

The group of molecular-based materials combinations often referred to as 'organic' or 'molecular' photovoltaic materials are of current great interest because of their potential in significantly reducing cost. The materials of current interest are conjugated molecular species, such as polymers, molecules and dyes, which are capable of absorbing light and conducting charge and thereby acting as organic semiconductors [1]. Their attraction lies primarily in the possibility of processing such materials directly from solution with the cost of the photoactive material falling by an order of magnitude [2,3]. Additionally, the less challenging manufacturing environment, compared, for example, with crystalline silicon wafer production, promises to reduce the capital cost for production facilities and to make the technology more widely accessible, especially in developing countries [4]. Moreover, it is also believed that if such materials are naturally synthesized and stable the cost could be further reduced. Dye Sensitized Solar Cells (DSSC) are one of the low cost alternatives for the conventional $\mathrm{p} / \mathrm{n}$ junction based solar cells, and commercially promising because it can be made from low-cost materials and do not require elaborated manufacturing facilities. At the moment there are dyes that can produce DSSCs with conversion efficiencies over $10 \%$ [5]. However, these types of dye suffer from the drawback that they are based on the rare Ru transition metal.

Asphaltenes are one of the materials that fulfill the requirements of organic semiconductors; i.e., absorbing a broad range of visible and near infrared light capable of conducting charge stable and naturally abundant [6-8]. Asphaltenes are organic materials that contains large number of structures, in particular high molecular weight fused aromatic hydrocarbons components with heteroatoms such as sulfur and nitrogen [9]. Asphaltenes also contain organic molecules such as Porphyrin already used in DSSC with promising performance. Most of the researchers have found that the sign of asphaltene charge is positive in organic solvent such as heptanes, toluene, ethanol, and nitro methane as studied by Zetametry and electrophoresis [10,11]. The origin of the electric charges is a consequence of an electron transfer between the organic solid particles and the liquid organic phase [12]. Asphaltenes are excellent candidates for use in DSSC as we report. This article introduces the first real data on using asphaltene fractions as sensitizer in DSSC and describes ways of improvements [13].

\section{Materials and Methods}

\section{Materials}

Commercial chemical agents and materials were used to prepare typical DSSCs, including $\mathrm{TiO}_{2}$ pastes, electrolytes and transparent

*Corresponding author: Chianelli RR, Materials Research and Technology Institute, University of Texas at El Paso, Texas, United States of America, Tel: 9157477555; E-mail: chianell@utep.edu

Received December 09, 2015; Accepted December 30, 2015; Published January 04, 2016

Citation: Abujnah RE, Sharif H, Torres B, Castillo K, Gupta V, et al. (2016) Asphaltene as Light Harvesting Material in Dye-Sensitized Solar Cell: Resurrection of Ancient Leaves. J Environ Anal Toxicol 6: 345. doi:10.4172/2161-0525.1000345

Copyright: (c) 2016 Abujnah RE, et al. This is an open-access article distributed under the terms of the Creative Commons Attribution License, which permits unrestricted use, distribution, and reproduction in any medium, provided the original author and source are credited. 
conductive glass FTO. The FTO are F-doped $\mathrm{SnO}_{2}$ from Solarnoix TCO30-8 SA Switzerland $8 \Omega / \mathrm{cm}^{2}$ and $3.3 \mathrm{~mm}$ thickness and 500 $1000 \mathrm{~nm}$ transmittance. The $\mathrm{TiO}_{2}$ paste was a highly transparent TiNanoxide HT/SP and Ti-Nanoxide R/SP obtained from Solaronix Co. Switzerland. The paste contains approximately $18 \%$ wt. of nano-crystalline titanium dioxide with $8-10 \mathrm{~nm}$ particle size, with terpineol and other organic binders. A layer of highly porous Anatase Nanocrystals is obtained after firing at $450^{\circ} \mathrm{C}$ for 30 minutes. The obtained sintered layer is highly transparent. Two types of commercial electrolytes obtained from Solaronix Company have been used in this study, which are Standard Iodolyte MPN-100. It consists of $100 \mathrm{mM}$ of tri-iodide in methoxypropionitrile solution. The second one is Iodolyte TG-50. It is Iodide Based Redox Electrolyte consists of $50 \mathrm{mM}$ of triiodide in tetraglyme.

\section{Asphaltene extraction and purification}

The crude oil (Mexican Altimira) was separated into Maltenes ( $\mathrm{n}$-heptane soluble) and Asphaltenes (n-heptane insoluble) by adding $\mathrm{n}$-heptanes in a volume-volume ratio of $\mathrm{n}$-heptanes to crude oil of 40:1, followed by filtration. $50 \mathrm{ml}$ of crude oil was mixed with 2000 $\mathrm{ml}$ of $\mathrm{n}$-heptane in a beaker, the mixture then stirred by magnetic tip overnight at room temperature. The solvent-to-oil ratio of 40:1 has been demonstrated to be suitable for avoiding errors in the determination of the amount of asphaltene fraction and in its characterization [14]. The mixture was filtered using a filter paper with a pore diameter of $8 \mu \mathrm{m}$. The Asphaltene was purified by dissolving it completely in toluene at room temperature and then filtered again to remove debris. The resulting solution of Asphaltene and toluene was covered and kept under vacuum at room temperature for 24 hours to dry out. The precipitated asphaltene then weighted for determining asphaltene content, marked as crude asphaltene and will be referred to as unfractionated asphaltene.

\section{Fractionation of asphaltene}

A sample of $3 \mathrm{~g}$ asphaltene was dissolved in $100 \mathrm{~mL}$ toluene, and $300 \mathrm{~mL} \mathrm{n}$-pentane was added into the solution and mixing by stirring with a magnetic bar at ambient temperature. After adding n-pentane, the ratio of the total volume of the n-pentane to toluene is kept at $75 / 25$ in volume. The solution was covered and stirred for half an hour for precipitation of insoluble. After filtration, the insoluble fraction was collected and dried at room temperature and left under vacuum overnight to obtain the first fraction (First precipitate Fr.1). Another amount of $270 \mathrm{ml}$ pentane then added to the filtrate n-pentane and toluene to keep the ratio of the total volume of the n-pentane to toluene at $85 / 15$ in volume.

The filtration and drying process then repeated to obtain the other fractions. Fraction two (Fr.2) was precipitated in a solution with an n-pentane to toluene ratio of $85 / 15$ in volume. Similarly, samples (Third precipitate. Fr.3) (n-pentane to toluene $=90 / 10$ ), were precipitated in binary solutions with the increasing proportion of $n$-pentane. The last fraction, (fourth precipitate Fr. 4), was obtained by evaporating the solvents with the remaining asphaltene.

\section{Preparation of the photo-electrode}

The blocking layer was prepared in the following manner. The FTO glass was first cleaned in a detergent solution using an ultrasonic bath for $15 \mathrm{~min}$, and then rinsed with water and ethanol, and treated with UV-O ${ }_{3}$ cleaner for 20 minutes after that the FTO glass plates were immersed into a $50 \mathrm{mM}$ aqueous solution of $\mathrm{TiCl}_{4}$ at $70^{\circ} \mathrm{C}$ for $30 \mathrm{~min}$ and washed with water and ethanol. The $\mathrm{TiCl}_{4}$ solution was formed by mixing $0.54 \mathrm{ml} \mathrm{TiCl}_{4}$ in $100 \mathrm{ml}$ of ultra-water in an ice path.

After applying the blocking layer, the photo electrodes then rinsed with d-water and ethanol and are ready for meso-layer application. The nanocrystalline $\mathrm{TiO}_{2}$ layer was prepared by applying two layers of TiNanoxide HT/SP paste by spreading (doctor blading). In the processes the FTO-coated glass was covered with two layers of parallel adhesive transparent tape $1 \mathrm{~cm}$ apart to control the area and the thickness of the $\mathrm{TiO}_{2}$ film $(2.5 \times 1 \mathrm{~cm})$ see Figure 1 . Tape is used to hold the slides as well as to create the spacing required to produce the nanoparticle film. A solution of Ti-Nanoxide HT/SP paste is then applied to the top slide. A glass road is then used to draw the solution down to the slide of interest in a smooth and quick motion to coat the working electrode with nanoparticles. The film is then left to dry and the tape is removed. Films are treated at $500^{\circ} \mathrm{C}$ for half an hour before soaking in a dye solution. This treatment process is used to remove any organic additives used as well as to sinter the nanoparticles together and remove any water from the active region of the cell. It is important to note that the samples should be hot $\left(70^{\circ} \mathrm{C}\right)$ when immersed in a dye solution to prevent $\mathrm{H}_{2} \mathrm{O}$ adsorption. The samples were left overnight in the dark for dye adsorption. The film is then cut into the desired cell area using a glasscutter and the Titania film is scratched into by $5 \mathrm{~mm}$ squares using a razorblade Figure 1.

\section{Preparation of the counter electrode}

Counter electrodes were fabricated by first drilling two holes using a diamond tip drill through an FTO piece of dimensions $2.5 \mathrm{~cm}$ by 5 $\mathrm{cm}$. Drops of water were applied during the drilling process to prevent fracture of the glass. Once the electrodes have holes in them, they are washed with a d-water and detergent solution using an ultrasonic bath for 20 minutes to remove any organic residues, then washed in Ethanol solution for 20 minutes and Acetone for 20 minutes and then cleaned with UV-O3 cleaner for 20 minutes just before Pt application. Before being used in a cell, counter electrodes are coated with platinum using a $5 \mathrm{mM}$ solution of Hexachloroplatinic acid in Ethanol. A few drops are placed on the counter electrode and left to dry for half an hour. The counter electrode is then heated at $450^{\circ} \mathrm{C}$ in a furnace for half an hour. Upon cooling, the counter electrode is ready to be used in a working cell.

\section{Assembling the cell}

Surlyn spacers are cut from a large sheet of Surlyn sandwiched between two grid paper sheets, into the desired cell active area of 10 $\mathrm{mm}$ by $15 \mathrm{~mm}$. After soaking the working electrode in dye solution overnight, the cells were assembled. To begin, the working electrodes are removed from the dye solution and washed with ethanol for 15 seconds waving mildly with tweezers. The electrode is then left to dry in a vertical position. The Surlyn gasket is placed around the Titania square and the counter electrode is then placed above the working electrode sandwiching the Surlyn gasket and placed under the hot press for 30 seconds. Once the Surlyn is melted (easily seen visually), the cell is left to cool in the dark. The next phase of cell assembly is to fill the solar cell with electrolyte and seal the cell. To do this, a Solaronix Vac'n'Fill Syringe was used to fill the electrolyte and Polyimide Film Tape with Acrylic Adhesive was used to cover the holes of the counter electrode see Figure 1.

\section{Results and Discussion}

\section{Introducing $\mathrm{TiO}_{2}$ blocking layer}

The importance of a blocking layer in organic dye-sensitized solar 


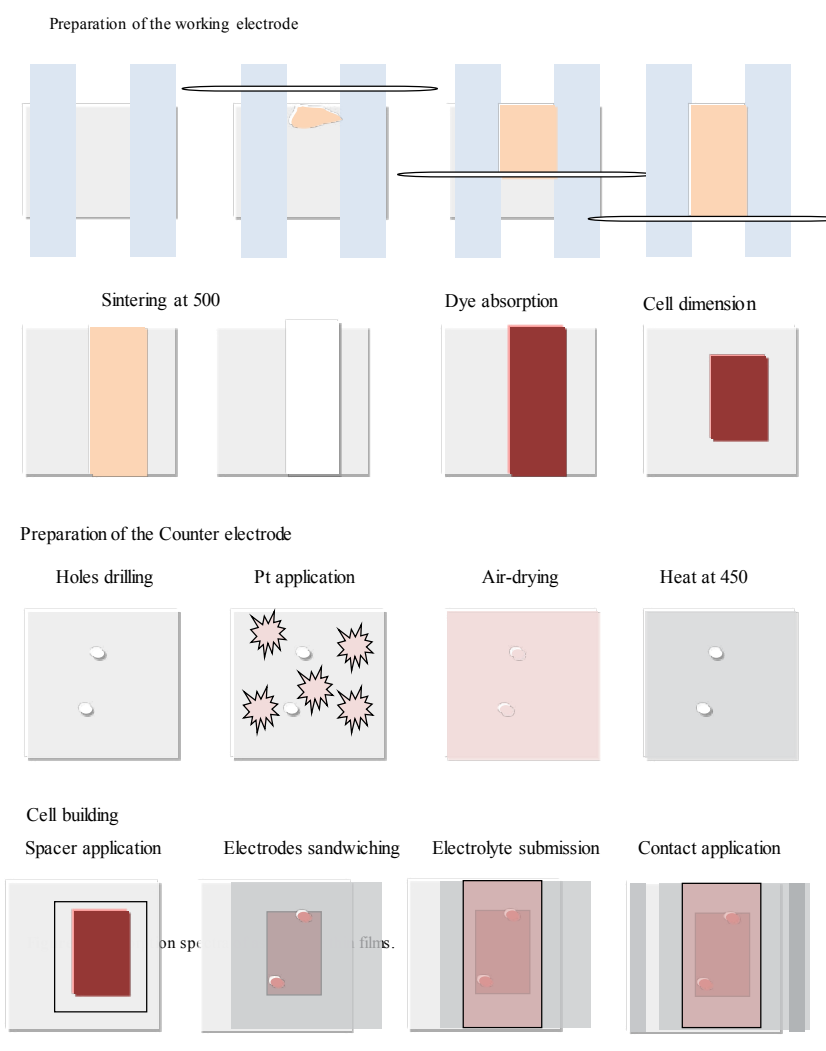

Figure 1: Processes of manufacturing DSSC.

cells has been demonstrated in many studies [14-17]. It was shown that upon the addition of a compact layer, the light-harvesting efficiencies were more than tripled. Such a compact layer improves the adhesion of the $\mathrm{TiO}_{2}$ to the TCO and provides a larger $\mathrm{TiO}_{2} / \mathrm{TCO}$ contact area and more effective electron transfer from the $\mathrm{TiO}_{2}$ to the $\mathrm{TCO}$ by preventing the electron recombination process, which occurs in the interface between the redox electrolyte and the TCO surface. The compact layer can be fabricated by various methods such as sputter deposition, dip-coating, chemical vapor deposition, and spray pyrolysis [14-17]. Especially, the fabrication of the $\mathrm{TiO}_{2}$ compact layer using a $\mathrm{TiCl}_{4}$ aqueous solution has been widely adopted and is the method used in this research [18].

To test the effect of the compact $\mathrm{TiO}_{2}$ layer on the performance of asphaltene solar cells we made two asphaltene solar cells both with three $\mathrm{TiO}_{2}$ layers (one compact and the other is Nano-crystalline layer). The used paste in these cells was commercial highly transparent Ti-Nanoxide HT/SP paste stated above, and the $\mathrm{TiO}_{2}$ compact layer was prepared using a $\mathrm{TiCl}_{4}$ aqueous solution. The asphaltene was unfractionated unpurified Altimira asphaltene obtained from Altimera crude oil with utilized concentration of $0.5 \mathrm{~g} / \mathrm{l}$. The cells were tested under solar simulator at standard condition of 1.5 sun and the results are shown in Table 1. It is clear that, the introduction of $\mathrm{TiO}_{2}$ compact layer prepared by the above mentioned method has increased the short circuit current, the close circuit voltage as well as overall cell efficiency.

The cells were tested under a solar simulator at standard condition of 1.5 sun and the results are shown in 5:34 PM. It is clear that, the introduction of $\mathrm{TiO}_{2}$ compact layer prepared by the above mentioned method has increased the short circuit current, the fill factor as well as overall cell efficiency.

\section{Purifying asphaltene and using RTV silicone rubber mask layer on the photoelectrodes}

A typical DSSC usually contains three interfaces formed by FTO/ $\mathrm{TiO}_{2}, \mathrm{TiO}_{2} /$ dye/electrolyte, and electrolyte/Pt-FTO. Simultaneously, electrons are transferred to tri-iodide at the $\mathrm{TiO}_{2} /$ dye/electrolyte interface and iodide is reduced to triiodide at the counter electrode. Series resistance in DSSC could arise from one of the above interfaces and have a great impact on cell performance. Varying the electrical properties of TCO, increasing the thickness of the electrolyte layer and the catalytic activity of the counter electrode, can raise the values of series resistance. Many researchers have found that, under short circuit conditions, electron transport was predominately affected by the series resistance in TCO-dye interface, and the electrolyte/Pt-TCO interface [19-21].

The extraction of asphaltene from crude oil involves dissolving the crude oil in $n$-heptanes followed by filtration. Asphaltene is the part of crude oil that does not dissolve and stay on top of the filter paper. Asphaltene extracted by this method could contain inorganic impurities, which may increase resistivity of the asphaltene films when applied on top of $\mathrm{TiO}_{2}$. Hence, it may have an effect on charge transfer and increases the series resistance at $\mathrm{TiO}_{2}$ /asphaltene/electrolyte interface. For this purpose we employed the purification method described above to take off these impurities, before using it in DSSC.

In addition to that, when applying the compact layer in our previous experiments, the FTO glass was immersed completely in a $\mathrm{TiCl}_{4}$ aqueous solution. Subsequently, $\mathrm{TiO}_{2}$ compact layer was formed on all the TCO coating of the FTO glass used to prepare the photoelctrode. This has shown to increase the resistivity of the TCO layer, for that reason we used RTV silicone rubber paste as mask and cover the backside of glass completely and leave less than half side of conducting surface uncovered, which will be used to deposit the paste. Following these two strategies the efficiency of our cells has increased significantly when compared to previous cells from 0.07 see Table 1 above to 0.25 see Table 2 below.

It is clear that the enhancement of cell efficiency in this cell was a consequence of decreasing series resistance and increasing close circuit current which leads to increase fill factor. This is in agreement of other people findings, which found an increase of FF with decrease in series resistance [22]. To study the effect of varying light intensity on cell performance, the cell was tested under three different intensity levels 80,100 , and $120 \mathrm{~mW} / \mathrm{cm}^{2}$. As was expected higher light intensity produces higher current density but less fill factor and therefore lower cell efficiency. This observation is a well-known phenomenon in DSSCs [23]. This is probably due to increase recommendation processes. The existence of the recombination process can be verified in the dark current measurement column five in the above table.

\section{UV-Ozone treatment of the photo-electrode}

The main components of the $\mathrm{TiO}_{2}$ pastes utilized in this study as well as in most DSSC research labs more than $\mathrm{TiO}_{2}$ particles are organic compounds used to disperse and link the semiconductor particles to form a network film. At high temperature sintering processes these compounds decompose and permit the formation of porous $\mathrm{TiO}_{2}$ films with high surface area. However, some carbon atoms will probably deposit on top of $\mathrm{TiO}_{2}$ particles and hinder the absorption of the dye, and the electron injection. $\mathrm{UV}-\mathrm{O}_{3}$ treatment is well known method to remove organics on transparent conducting oxides and has been widely used in organic electronic devices to clean the surface and modify 
the work function of ITO. Recently UV-O treatment was applied to synthesize porous nano-particulate $\mathrm{TiO}_{2}$ films at room temperature and remarkable improvement of photo-conversion efficiency was obtained using the treatment. It is believed that the main effect of the $\mathrm{UV}-\mathrm{O}_{3}$ treatment was reported to be the removal of residual organics and positive shift in the conduction band of the nano-crystalline titanium dioxide, which promotes electron injection from the dye [24,25].

To see if UV-O $\mathrm{O}_{3}$ treatment has an effect on the performance of asphaltene solar cells, $\mathrm{UV}-\mathrm{O}_{3}$ treatment was first applied on the last $\mathrm{TiO}_{2}$ layer. Two asphaltene cells were made this time one with the commercial paste and the other is homemade paste described above. Both cells have given much better Voc and photocurrent when compared to the previous cells without UV-O ${ }_{3}$ treatments see Table 3 .

After, our $\mathrm{UV}-\mathrm{O}_{3}$ treatment on top layer of the photo-electrode showed improvement in cell operation, we apply UV-O ${ }_{3}$ in three processing steps on bare FTO before the compact layer, before and after the compact layer and after the mesolayer. The used asphaltene here was fr.2 asphaltene with applying concentration of $1 \mathrm{mg} / \mathrm{ml}$. Due to difficulty of applying the previous sealing material, the sealant has changed to Polypropylene w/ Rubber Medium Adhesive tape with 228.6 micrometers thick obtained from Grainger company item no 6JT54, the adhesive was not strong enough so some drops of crazy glue was put in on top of the tape between the electrodes. So the thickness was further increased a few micrometers. The results are shown in Table 4.

The efficiency of these cells has increased four times when compared with the ones without $\mathrm{UV}-\mathrm{O}_{3}$ treatment. The improvement in efficiency was a result of a big boost in both short circuit current and open circuit voltage. This enhancement was a result of increase in asphaltene absorption, eliminating organic contamination and therefore, higher photon capture and higher electron injection. However these cells shows very low fill factor. The decrease in the fill factor is due to increasing the electrolyte thickness as a result of increasing the sealant layer. The electrolyte ions will take longer time to reach the counter electrode before it reduced back. Similar results were observed with increasing the electrolyte thickness.

The low photo current in asphaltene solar cell when $\mathrm{UV}-\mathrm{O}_{3}$ treatment was done on all the three $\mathrm{TiO}_{2}$ layers was probably due to electrolyte touching the counter electrode because of improper sealing. So changing the sealant is vital at this point.

\section{Varying asphaltene fraction}

The open circuit voltage and short circuit current are both depend on the extent of light absorption. The most straightforward way to increase JSC is to absorb a greater fraction of the incident light. The optical gap of the Ru dye in the most efficient DSSC to date is $1.8 \mathrm{eV}$, allowing it to absorb essentially all the light out to $700 \mathrm{~nm}$. Increasing the photocurrent density requires decreasing the optical gap to extend the dye's absorption into the near infrared. Our first thought of increasing short circuit current is to try different asphaltene fraction. Fractionation of asphaltene produces slightly different absorption spectra (Figure 2).

Neglecting the fill factor at the moment, the cells made of fr. 4, which is the most toluene soluble fraction, produces the less photocurrent and photo voltage when compared to the other asphaltene fractions. The less soluble asphaltene part (fraction one) generates higher photo voltage but lower photocurrent then fr.2 (Table 5) fr.3, and un-fractionated asphaltene.

\begin{tabular}{|l|l|l|l|l|l|}
\hline Cell id & Voc $(\mathbf{v})$ & Jsc (mA/cm & FF $\%$ & IPCE \% & Voc Slope (ohms) \\
\hline Without compact & 0.4784 & 0.158 & 35.42 & 0.03 & 1830 \\
\hline With compact & 0.420 & 0.388 & 46.46 & 0.07 & 398 \\
\hline
\end{tabular}

Table 1: The effect of $\mathrm{TiO}_{2}$ compact layer on asphaltene cell performance.

\begin{tabular}{|l|l|l|l|}
\hline Iv parameter & $\mathbf{8 0} \mathbf{~} \mathbf{W} / \mathbf{c m}^{\mathbf{2}}$ & $\mathbf{1 0 0} \mathbf{~} \mathbf{W} / \mathbf{c m}^{\mathbf{2}}$ & $\mathbf{1 2 0} \mathbf{~} \mathbf{W} / \mathbf{c m}^{\mathbf{2}}$ \\
\hline Voc $(\mathrm{V})$ & 0.54 & 0.55 & 0.54 \\
\hline Jsc $\left(\mathrm{mA} / \mathrm{cm}^{2}\right)$ & 0.59 & 0.72 & 0.91 \\
\hline Fill factor \% & 65.4 & 63.2 & 60.6 \\
\hline Voc slope (Ohms) & 43.6 & 42.6 & 38.7 \\
\hline Efficiency (\%) & 0.26 & 0.25 & 0.25 \\
\hline
\end{tabular}

Table 2: Purified Un-fractionated Altimira asphaltene cell parameters with $0.5 \mathrm{gm} / \mathrm{l}$.

\begin{tabular}{|l|l|l|l|l|}
\hline Cell ID & Voc (V) & Jsc $\mathbf{~} \mathbf{m A} / \mathbf{c m}^{2}$ & FF $\%$ & IPCE \% \\
\hline Ti HT/SP+R & 0.806 & 8.51 & 15 & 1.03 \\
\hline H P25+R & 0.809 & 6.77 & 14.7 & 0.8 \\
\hline
\end{tabular}

Table 3: The effect of UV-O treatment on top $\mathrm{TiO}_{2}$ layer.

\begin{tabular}{|l|l|l|l|l|l|l|}
\hline IPCE (\%) & Voc (V) & $\begin{array}{l}\text { Jsc (mA/ } \\
\mathbf{c m}^{2} \text { ) }\end{array}$ & FF (\%) & FTO UVO & CL UVO & ML UVO \\
\hline 1.44 & 0.8252 & 13.19 & 13.1 & X & & X \\
\hline 1.34 & 0.7818 & 13.55 & 12.9 & $X$ & $X$ & \\
\hline 0.76 & 0.7790 & 7.74 & 12.2 & $X$ & $X$ & $X$ \\
\hline
\end{tabular}

Table 4: The effect of ozone treatment on the asphaltene DSSC.

\begin{tabular}{|l|l|l|l|l|}
\hline IPCE (\%) & Voc (V) & Jsc $\left(\mathbf{m A} / \mathbf{c m}^{2}\right)$ & FF $\mathbf{( \% )}$ & Frac \# \\
\hline 1.80 & 0.7793 & 13.69 & 16.6 & 3 \\
\hline 1.38 & 0.7098 & 4.76 & 40.1 & 4 \\
\hline 1.02 & 0.7724 & 10.52 & 13.0 & 1 \\
\hline 1.76 & 0.7744 & 13.45 & 13.0 & Unfrac \\
\hline
\end{tabular}

Table 5: Asphaltene fraction cell parameters.

These results are in agreement with the absorption spectra of asphaltene thin films presented in Figure 2. Both Fr.1 and Fr.4 have lower absorption in the visible part of light and therefore, will have lower photocurrent. The high fill factor in Fr.4 cell is a result of changing the sealant to lower thickness and easy to process fastelfilm 230110 with 130 micrometer thick film, obtained from Fastel Adhesive.

\section{Conclusion}

The essence of this research work is well encapsulated by the title of this work, namely, "Asphaltene as light harvesting material in dye sensitized solar cell". Despite the fact that there were considerable doubts about the suitability of these materials as sanitizer in DSSC at the start of this work, the research presented in this article has comes a long way in removing many of these reservations. It has been proved that for at least one part of the asphaltene or asphaltene in whole can be effectively utilized. Asphaltene indeed is an excellent sanitizer in DSSC. Asphaltene the most abundant naturally forming material and undesirable part of crude oil that causes a lot of trouble to most oil refining companies has been shown in this study to be good sensitizer in DSSC. The results obtained show that every step in manufacturing the asphaltene cell has an effect on different cell parameters. According to results shown above, asphaltene solar cells have achieved a fill factor of $65 \%-70 \%$, when series resistance was minimized, Voc of $0.7-0.8$ volt, and photocurrent of $10-13.69 \mathrm{~mA} / \mathrm{cm}^{2}$ when $\mathrm{UV}-\mathrm{O}_{3}$ treatment were employed and contaminates were eliminated. Therefore, a total overall efficiency of $4.55 \%-7.0 \%$ could be easily attained with good engineering design and material process. Fraction three (Fr.3) obtained at 90/10 
Citation: Abujnah RE, Sharif H, Torres B, Castillo K, Gupta V, et al. (2016) Asphaltene as Light Harvesting Material in Dye-Sensitized Solar Cell: Resurrection of Ancient Leaves. J Environ Anal Toxicol 6: 345. doi:10.4172/2161-0525.1000345

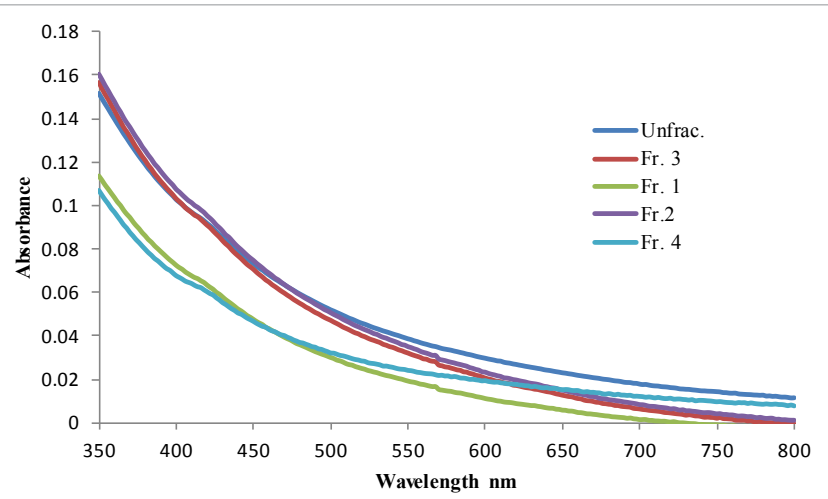

Figure 2: Absorption spectra of asphaltene thin films.

pentane to toluene ratio has produced the best asphaltene solar cell so far with 1.8 total efficiency. Un-fractionated asphaltene produced comparable result with Fr.3. Asphaltene photovoltaic as described above also exhibited long-term stability.

\section{References}

1. Troshin PA, Lyubovskaya RN, Razumov VF (2008) Organic solar cells: structure, materials, critical characteristics, and outlook. Nanotechnologies in Russia 3: 5-6.

2. Shaheen SE, Ginley DS, Jabbour GE (2005) Organic-based photovoltaics: toward low-cost power generation. Mater Res Bul 30: 10-19.

3. Kalowekamo J, Baker E (2009) Estimating the manufacturing cost of purely organic solar cells. Solar Energy 83: 1224-1231.

4. Brabec CJ (2004) Organic photovoltaics: technology and market. Solar Energy Materials and Solar Cells 83: 273-292.

5. Gratzel M (2003) Dye-sensitized solar cell. J Photochem Photobio C 4: 145153.

6. Ruiz-Morales Y, Mullins OC (2007) Electronic absorption edge of crude oils and asphaltenes analyzed by molecular orbital calculations with optical spectroscopy. Energy \& Fuels 21: 944-952.

7. Salmanova CK, Akhmedbekova SF, Mamedov AP, Kyazimov SM, Abdulova S (2007) Transformation of resins and asphaltene in photoirradiatio. Chem Tech of Fuels \& Oils 43: 415-421.

8. Wang J, Li C, Zhang L, Que G, Li Z (2009) The properties of asphaltenes and their interaction with amphiphiles. Energy \& Fuels 23: 3625-3631.

9. Mullins OC, Sheu EY, Hammami A, Marshall A (2007) Asphaltenes. Heavy Oils, and Petroleomics.
10. Siffert B, Kuczinski J, Papirer E (1990) Relationship between electrical charge and flocculation of heavy oil distillation residues in organic medium. J Colloid Interface Sci 135: 107-117

11. Neves GBM, de Sousa MA, Travalloni-Louvisse AM, Lucas EF, Gonz'alez G (2001) Characterization of asphaltene particles by light scattering and electrophoresis. Petro Sci Tech 19: 35-43.

12. Chianelli RR, Castillo K, Gupta V, Qudah AM, Torres B, et al. (2013) Asphaltene based photovoltaic devices. US 8: 389-853.

13. Ancheyta J, Centeno G, Trejo F, Marroquín G, García JA, et al. (2002) Extraction and characterization of asphaltenes from different crude oils and solvents. Energy \& Fuel 16: 1121-1127.

14. Ito S, Liska P, Comte P, Charvet R, Pechy P, et al. (2005) Control of dark current in photoelectrochemical $\left(\mathrm{TiO}_{2} / \mathrm{l} / \mathrm{I}\right)$ and dye-sensitized solar cells. Chem Comm 34: 4351-4353.

15. Gan WY, Lam SW, Chiang K, Amal R, Zhao H, et al. (2007) Novel $\mathrm{TiO}_{2}$ thin film with non-UV activated super wetting and anti fogging behaviours. J Mater Chem 17: 952-954.

16. Thelakkat M, Schmitz C, Schmidt HW (2002) Fully vapor-deposited thin layer titanium dioxide solarcells. Adv Mater 14: 577-581.

17. Okuya M, Nakade K, Kaneko S (2002) Porous $\mathrm{TiO}_{2}$ thin films synthesized by aspray pyrolysis deposition(spd) technique and their application to dyesensitized solar cells. Sol Ener Mater Sol Cells 70: 425-435.

18. Ito S, Chen P, Comte P, Nazeeruddin MK, Liska P (2007) Fabrication of screen-printing pastes from tio2 powders for dye-sensitised solar cells. Prog Photovoltaics 15: 603-612.

19. Hoshikawa T, Yamada M, Kikuchi R, Eguchi K (2005) Impedance analysis fo dye-sensitized solar cells with a three-electrode system. J Electroanalytical Chem 577: 339-348.

20. Anneke H, Georg A (2001) Diffusion in the electrolyte and charge-transfer reaction at the platinum electrode in dye-sensitized solar cells. Electrochimica Acta 46: 3457-3466.

21. Weiqing L, Linhua H, Songyuan D, Lei G, Nianquan J, et al. (2010) The effect of the series resistance in dye-sensitized solar cells explored by electron transport and back reaction using electrical and optical modulation. Electrochimica Acta 55: 2338-2343.

22. Naoki K, Islam A, Yasuo C, Han L (2006) Improvement of efficiency of dyesensitized solar cells based on analysis of equivalent circuit. J Photochem Photobio A: Chem 182: 296-305.

23. Lee KM, Suryanarayananb V, Hoc KC (2009) High efficiency quasi-solidstate dye-sensitized solar cell based on polyvinyidene fluoride-co-hexafluoro propylene containing propylene carbonate and acetonitrile as plasticizers. J Photochem Photobio A: Chem 207: 224-230.

24. Lee BK, Kim JJ (2009) Enhanced efficiency of dye-sensitized solar cells by $\mathrm{UV}-\mathrm{O}_{3}$ treatment of $\mathrm{TiO}_{2}$ layer. Curr Appl Phys 9: 404-408.

25. Zhang D, Yoshida T, Oekermann T, Furuta K, Minoura H (2006) Roomtemperature synthesis of porous nanoparticulate tio2 films for flexible dyesensitized solar cells. Adv Func Mater 16: 1228-1234. 